\title{
EVALUASI PERAN PENDIDIKAN KEWIRAUSAHAAN PADA SEKOLAH MENENGAH KEJURUAN
}

\author{
Eko Prasetyo ${ }^{1,2}$ \\ ${ }^{1}$ SMK Negeri Tempursari Kabupaten Lumajang \\ ${ }^{2}$ Sekolah Tinggi Ekonomi Syariah Ihya' Ulumiddin \\ Jalan KH. Abdullah Hasbullah, Nomor 08 Padang, \\ Kecamatan Singojuruh, Banyuwangi, Jawa Timur - 68464 \\ e-mail: edunomi@gmail.com
}

\begin{abstract}
Abstrak
Penelitian bertujuan untuk mengukur pengaruh entrepreneurial self-efficacy (ESE), entrepreneurial attitude (EA), dan entrepreneurial intention (EI) terhadap pendidikan kewirausahaan. Subjek penelitian yaitu seluruh siswa SMK Negeri Tempursari. Penelitian yang dilakukan merupakan penelitian populasi dengan jumlah 187 siswa. Instumen penelitian menggunakan angket. Teknik analisis data menggunakan MANOVA. Hasil penelitian yaitu: (1) Nilai rata-rata (mean) ESE, EA, dan EI siswa yang telah mendapatkan pendidikan kewirausahaan lebih tinggi apabila dibandingkan dengan nilai rata-rata siswa yang belum mendapatkan pendidikan kewirausahaan; dan (2) EA dan EI tidak terdapat pengaruh yang signifikan antara siswa yang telah mendapatkan pendidikan kewirausahaan dan siswa belum mendapatkan pendidikan kewirausahaan. Sedangkan pada aspek ESE terdapat pengaruh yang signifikan antara siswa yang telah mendapatkan pendidikan kewirausahaan dan siswa yang belum mendapatkan pendidikan kewirausahaan.
\end{abstract}

Kata Kunci: pendidikan kewirausahaan, entrepreneurial self-efficacy, entrepreneurial attitude, entrepreneurial intention.

\begin{abstract}
The research aims to measure the effect of entrepreneurial self-efficacy (ESE), entrepreneurial attitude (EA), and entrepreneurial intention (EI) towards entrepreneurship education. The research subjects were all students of SMK Negeri Tempursari. Research conducted is a population study with a total of 187 students. The research instrument used a questionnaire. Data analysis used the MANOVA technique. The results of the study were: (1) The mean value of the ESE, EA, and EI of students who have received entrepreneurship education is higher when compared to the average value of students who have not received entrepreneurship education; and (2) EA and EI have no significant effect between students who have received entrepreneurship education and students who have not received entrepreneurship education. While in the ESE aspect there is a significant influence between students who have received entrepreneurship education and students who have not received entrepreneurship education.
\end{abstract}

Keywords: entrepreneurship education, entrepreneurial self-efficacy, entrepreneurial attitude, entrepreneurial intention

\section{PENDAHULUAN}

Pendidikan kewirausahaan merupakan sebuah proses panjang yang bermuara pada upaya untuk menumbuhkan lahirnya wirausahawan baru. Banyak 
negara seolah berlomba untuk terus meningkatkan kualitas pendidikan kewirausahaan. Harapannya tentu saja agar dapat meningkatkan pertumbuhan wirausaha baru. Dalam konteks Indonesia, pendidikan kewirausahaan telah diajarkan di sekolah formal pada berbagai tingkatan. Tujuan utama pengajaran pendidikan wrausaha pada sekolah formal di Indonesia adalah untuk meningkatkan intensi wirausaha pada para siswa (Mahendra, dkk., 2017). Sekolah Menengah Kejuruan (SMK) merupakan salah satu lembaga pendidikan formal yang juga mengajarkan kewirausahaan secara terstruktur. SMK disiapkan untuk tidak hanya menyiapkan lulusan yang siap kerja, namun juga siap menjadi pengusaha muda (Nurmaliza, dkk., 2018).

Secara faktual, justru lulusan SMK menjadi penyumbang pengangguran terbesar di Indonesia. Dari tahun 2015 sampai dengan 2018, lulusan SMK menunjukkan angka tertinggi penyumbang pengangguran. Berdasarkan data Badan Pusat Statistik (BPS) mempublikasikan data pengangguran terbuka menurut pendidikan tertinggi. Pada tahun 2015, lulusan SMK merupakan penyumbang pengangguran tertinggi kedua (yang pertama adalah lulusan sekolah menengah atas) dengan jumlah 1.569 .690 orang (20,76\%). Kondisi yang sama berlanjut pada tahun 2016, lulusan SMK masih menjadi penyumbang pengangguran terbesar kedua dengan jumlah 1.520 .549 orang $(21,62 \%)$. Pada tahun 2017, lulusan SMK masih menjadi penyumbang pengangguran terbesar kedua dengan jumlah 1.621.402 orang (23,15\%). Dan pada tahun 2018, lulusan SMK masih menjadi penyumbang pengangguran terbesar kedua dengan jumlah 1. 731.743 orang $(24,74 \%)$.

Upaya revitalisasi pendidikan kejuruan berbasis kewirausahaan terus dilakukan (Sunyoto, dkk., 2018). Perubahan besar tersebut dimulai pada akhir 2013. Perubahan tersebut terkait dengan filosofi pembelajaran, perbaikan isi materi yang diajarkan, perbaikan model pembelajaran serta penambahan lama waktu pembelajaran dari 2 jam pelajaran menjadi 7 jam pelajaran per minggu (Nurmaliza, dkk., 2018). Namun kemudian muncul pertanyaan, apakah perubahan besar pada konteks pendidikan kewirausahaan pada jenjang sekolah kejuruan di 
Indonesia akan memberikan dampak yang baik bagi para siswa? Pertanyaan penting tersebut yang menjadi dasar dilaksanakan penelitian.

Pendidikan kewirausahaan tidak hanya mengajarkan tentang wirausaha, namun juga mengolah sikap dan minat terhadap wirausaha (Linan, 2008). Ada berbagai jenis dan tingkatan pendidikan kewirausahaan yang telah dilakukan yang disesuaikan dengan siswa dan tujuan pendidikan kewirausahaan. Salah satu jenis pendidikan kewirausahaan yang banyak diterapkan diberbagai institusi pendidikan adalah pendidikan kewirausahaan untuk membangun kesadaran wirausaha.

Pendidikan kewirausahaan untuk membangun kesadaran wirausaha ditujukan untuk para siswa yang belum pernah menjadi wirausaha. Tujuan program tersebut adalah untuk membangun kesadaran, ketertarikan, dan menyiapkan para siswa untuk menjadi pengusaha setelah lulus sekolah (Bae, et al., 2014). Pendidikan kewirausahaan untuk membangun kesadaran wirausaha berupaya untuk meningkatkan entrepreneurial intention (EI) para siswa (Linan, 2008). Alasan logis yang disampaikan bahwa EI merupakan prediktor terbaik perilaku kewirausahaan (Autio, et al., 2001; Kautonen, et al., 2015). Semakin tinggi EI siswa, semakin besar kemungkinan bagi siswa untuk mewujudkan intensi tersebut dalam tindakan nyata dengan menjadi pengusaha suatu saat nanti (Autio, et al., 2001; Engle, et al., 2010; Iakovleva, et al., 2011; Linan and Chen, 2009).

EI merupakan ketertarikan untuk memilih karir sebagai seorang wirausaha (Autio, et al., 2001). EI juga merupakan sebuah pengakuan secara sadar bahwa seseorang akan mendirikan dan memulai bisnis baru, untuk kemudian melaksanakan langkah langkah berikutnya pada masa yang akan datang (Thompson, 2009). EI mencermintakan ketertarikan individu untuk membuka sebuah bisnis (Engle, et al., 2010). EI merupakan fokus kajian utama yang diasumsikan dapat memprediksi tindakan dengan baik (Al-Jubari, et al., 2018; Autio, et al., 2001; Linan \& Chen, 2009).

EI merupakan salah satu prediktor terbaik yang mampu menggambarkan sebuah perilaku pada masa mendatang (Krueger, et al., 2000). EI membantu memahami mengapa seseorang tertarik untuk membuka sebuah bisnis jauh 
sebelum menemukan kesempatan dan ide bisnis yang spesifik (Engle, et al., 2010). Lahirnya bisnis baru merupakan hasil dari perencanaan dan pemikiran yang cermat dan disengaja. EI merupakan sebuah titik awal proses pemikiran, perencanaan, dan kesengajaan (Bird, 1988). Semakin besar niat kewirausahaan seseorang, semakin kuat dorongan yang ada pada dirinya untuk mewujudkannya dalam tindakan nyata dengan membuka sebuah bisnis baru (Kautonen et al., 2015). Pada konteks pelajar, semakin tinggi niat kewirausahaan, semakin besar potensi untuk memulai sebuah bisnis, baik ketika masih menjadi pelajar atau setelah lulus nanti (Nowiński, et al., 2017; Sun, et al., 2016).

EI dipengaruhi oleh beberapa antecedent. Entrepreneurial attitude (EA) merupakan salah satu antecedent EI yang paling kuat dan konsisten. EA merupakan cerminan penilaian positif atau negativf atas kemungkinan untuk mendirikan dan mengelola sebuah bisnis secara mandiri (Ajzen, 2001; Autio et al., 2001). Penilaian tersebut tidak hanya didasarkan pada aspek suka dan tidak suka (afektif) saja, namun juga melibatkan proses evaluasi yang telah dipertimbangakan secara matang (Linan and Chen, 2009). Sikap merupakan pembeda makna sebuah fakta. Kenyataan yang sama akan dipersepsikan berbeda, jika sikap yang mendasarinya berbeda (Ajzen, 2001).

Entrepreneurial self-efficacy (ESE) merupakan antecedent lain yang turut berpengaruh terhadap EI. ESE mencerminkan pengukuran terhadap keyakinan individu secara spesifik terkait dengan kemampuan yang dimiliki untuk bisa sukses dalam proses kewirausahaan (McGee, et al., 2009). Keyakinan atas kemampuan spesifik tersebut meliputi empat kemampuan khusus, yakni mencari ide bisnis, merencanakan bisnis, marshaling, dan implementasi (Kickul, et al., 2009). ESE merupakan keyakinan yang terbentuk sebagai hasil internalisasi diri dan persepsi yang dibangun sebagai pengaruh dari lingkungan (Newman, et al., 2018).

Beberapa pengukuran tentang efektivitas pendidikan kewirausahaan menggunakan EI dan komponen theory of planned behavior (TPB) sebagai tolok ukur keberhasilan pelaksanaan pendidikan kewirausahaan telah dilakukan (Galvão, et al., 2018; Marques, et al., 2012; Nowiński, et al., 2017). Beberapa 
penelitian lainnya mengkomparasikan siswa yang mengikuti pendidikan kewirausahaan dan tidak mengikuti kewirausahaan (Solesvik, et al., 2014; Solesvik, 2013; Westhead and Solesvik, 2015). Temuan para peneliti yang telah dilakukan menunjukkan hasil yang tidak sama. Beberapa menemukan bahwa pendidikan kewirausahaan tidak mampu memberikan peningkatan dan pengaruh terhadap EI (Galvão, et al., 2018; Marques, et al., 2012; Nowiński, et al., 2017). Temuan berbeda menunjukkan bahwa pendidikan kewirausahaan dapat mendorong peningkatan entrepreneurial intention bagi siswa (Rauch and Hulsink, 2015; Solesvik, et al., 2014;).

Berdasarkan uraian tersebut, maka dilakukan penelitian untuk mengukur pengaruh entrepreneurial self-efficacy, entrepreneurial attitude, dan entrepreneurial intention terhadap pendidikan kewirausahaan di SMK Negeri Tempursari.

\section{METODE}

Jenis penelitian yang digunakan adalah korelasional. Variabel yang diukur pengaruhnya adalah entrepreneurial self-efficacy (ESE) yang dinotasikan dengan simbol X1, variabel entrepreneurial attitude (EA) yang dinotasikan dengan simbol X2, variabel entrepreneurial intention (EI) yang dinotasikan dengan X3, dan pendidikan kewirausahaan yang dinotasikan dengan Y. Teknik MANOVA digunakan untuk mengukur pengaruh ESE, EA, dan EI terhadap pendidikan kewirausahaan pada siswa yang telah dan belum mendapatkan pembelajaran kewirausahaan.

Penelitian yang dilakukan merupakan penelitian populasi. Populasi penelitian yaitu seluruh siswa SMK Negeri Tempursari yang berjumlah 187 siswa. Sebanyak 61 siswa kelas $\mathrm{X}$ yang merupakan kelompok siswa yang belum mengikuti pendidikan kewirausahaan, 65 siswa merupakan siswa kelas XI yang telah menempuh pendidikan kewirausahaan di tahun pertama, dan 61 siswa merupakan siswa kelas XII yang telah menempuh pendidikan kewirausahaan di tahun kedua. 
Pengumpulan data menggunakan angket. Pengembangan angket penelitian dilakukan dengan mengacu pada instrumen yang telah dikembangkan oleh para peneliti sebelumnya. Instrumen ESE mengacu pada instumen yang dikembangkan oleh Kickul, et al. (2009). Sedangkan variabel EA dan EI mengacu pada Linan dan Chan (2009). Pengukuran instrumen dilakukan dengan menggunakan skala Likert, antara 1-5. Nilai 1 untuk menunjukkan bahwa sangat tidak setuju dan nilai 5 untuk menunjukkan bahwa partisipan sangat setuju.

Pengukuran pendidikan kewirausahaan menggunakan variabel dummy, skor "0" diberikan untuk siswa yang belum menempuh pendidikan kewirausahaan (siswa kelas X), skor "1" diberikan untuk siswa kelas XI yang telah menempuh pendidikan di tahun pertama (pendidikan kewirausahaan level 1), dan nilai "2" diberikan untuk siswa kelas XII yang telah mengikuti pendidikan kewirausahaan di tahun kedua (pendidikan kewirausahaan level 2). Angket yang digunakan berbasis digital. Peneliti mengirimkan link angket digital kepada para siswa.

\section{HASIL DAN PEMBAHASAN}

Hasil

Hasil uji secara deskriptif terdapat pada tabel berikut.

Tabel 1 Hasil Analisis Deskriptif

\begin{tabular}{|c|c|c|c|c|}
\hline Variabel & Sampel & Mean & St. Deviasi & $\mathbf{N}$ \\
\hline \multirow[t]{4}{*}{ ESE } & Non Pend. KWU & 22,94 & 5,056 & 61 \\
\hline & Pend. KWU Level 1 & 24,64 & 4,073 & 65 \\
\hline & Pend. KWU level 2 & 24,80 & 4,096 & 61 \\
\hline & Total & 24,26 & 4,408 & 187 \\
\hline \multirow[t]{4}{*}{ EA } & Non Pend. KWU & 12,62 & 2,737 & 61 \\
\hline & Pend. KWU Level 1 & 12,92 & 2,594 & 65 \\
\hline & Pend. KWU level 2 & 13,26 & 2,193 & 61 \\
\hline & Total & 12,96 & 2,504 & 187 \\
\hline \multirow[t]{4}{*}{ EI } & Non Pend. KWU & 11,98 & 3,017 & 61 \\
\hline & Pend. KWU Level 1 & 12,24 & 2,601 & 65 \\
\hline & Pend. KWU level 2 & 12,54 & 2,311 & 61 \\
\hline & Total & 12,28 & 2,620 & 187 \\
\hline
\end{tabular}

Berdasarkan data pada Tabel 1, diketahui bahwa terdapat perbedaan dari aspek EA, ESE, dan EI pada siswa yang belum mendapatkan pendidikan 
kewirausahaan dengan siswa yang telah mendapatkan pendidikan kewirausahaan. Nilai rata-rata (mean) Pend. KWU Level 1 dan Pend. KWU Level 2 lebih tinggi apabila dibandingkan dengan nilai rata-rata Non Pend. KWU. Hal tersebut wajar saja dikarenakan siswa pada Non Pend. KWU belum mendapatkan pembelajaran pendidikan kewirausahaan.

Tabel 2 memperlihatkan hasil analisis MANOVA untuk mengukur pengaruh dari variabel-variabel yang diteliti.

Tabel 2 Hasil Uji MANOVA

\begin{tabular}{cllccc}
\hline Variabel & (I) Pend. KWU & (J) Pend. KWU & Mean Difference (I-J) & Std. Error & Sig. \\
\hline ESE & NON KWU & KWU LEVEL 1 & $-1,70^{*}$ & 0,621 & 0,018 \\
& & KWU LEVEL 2 & $-1,86^{*}$ & 0,636 & 0,010 \\
& \multirow{2}{*}{ KWU LEVEL 1 } & NON KWU & $1,70^{*}$ & 0,621 & 0,018 \\
& & KWU LEVEL 2 & $-0,16$ & 0,568 & 0,956 \\
& KWU LEVEL 2 & NON KWU & $1,86^{*}$ & 0,636 & 0,010 \\
& & KWU LEVEL 1 & 0,16 & 0,568 & 0,956 \\
\hline EA & NON KWU & KWU LEVEL 1 & $-0,31$ & 0,357 & 0,659 \\
& & KWU LEVEL 2 & $-0,644$ & 0,365 & 0,184 \\
& \multirow{2}{*}{ KWU LEVEL 1 } & NON KWU & 0,31 & 0,357 & 0,659 \\
& & KWU LEVEL 2 & $-0,33$ & 0,326 & 0,564 \\
& \multirow{2}{*}{ KWU LEVEL 2 } & NON KWU & 0,644 & 0,366 & 0,184 \\
& & KWU LEVEL 1 & 0,33 & 0,326 & 0,564 \\
\hline \multirow{2}{*}{ EI } & NON KWU & KWU LEVEL 1 & $-0,26$ & 0,374 & 0,759 \\
& & KWU LEVEL 2 & $-0,57$ & 0,383 & 0,304 \\
& \multirow{2}{*}{ KWU LEVEL 1 } & NON KWU & 0,26 & 0,374 & 0,759 \\
& & KWU LEVEL 2 & $-0,30$ & 0,342 & 0,653 \\
& KWU LEVEL 2 & NON KWU & 0,57 & 0,383 & 0,304 \\
& & KWU LEVEL 1 & 0,30 & 0,342 & 0,653 \\
\hline
\end{tabular}

Berdasarkan Tabel 2, diketahui bahwa pada aspek EA dan EI tidak terdapat pengaruh yang signifikan antara siswa yang telah mendapatkan pendidikan kewirausahaan dan siswa yang belum mendapatkan pendidikan kewirausahaan. Sedangkan pada aspek ESE terdapat pengaruh yang signifikan antara siswa yang telah mendapatkan pendidikan kewirausahaan dan siswa yang belum mendapatkan pendidikan kewirausahaan. Pada siswa kelas XI dan kelas XII tidak terdapat pengaruh yang signifikan pada aspek ESE. Artinya semakin lama siswa mengikuti pendidikan kewirausahaan tidak memberikan dampak yang berarti pada aspek ESE. 


\section{Pembahasan}

Berdasarkan hasil analisis dan uraian terhadap data penelitian, diketahui bahwa pendidikan kewirausahaan yang diterapkan di SMK Negeri Tempusari termasuk tidak memiliki pengaruh yang signifikan. Minat wirausaha (EI) sebagai indikator penilaian keberhasilan pendidikan kewirausahaan terbukti tidak menunjukkan pengaruh yang signifikan antara siswa yang telah mengikuti pendidikan kewirausahaan dan siswa yang belum mengikuti pendidikan kewirausahaan. Artinya tanpa pendidikan kewirausahaan para siswa tetap memiliki minat terhadap pendidikan kewirausahaan. Hasil penelitian yang dilakukan oleh Mahendra, dkk. (2017) menyimpulkan bahwa tidak terdapat pengaruh dari pelaksanaan pendidikan kewirausahaan terhadap EI mahasiswa.

Hasil yang juga tidak berbeda ditunjukkan pada aspek EA. Tidak ada pengaruh yang signifikan tentang sikap siswa terhadap wirausaha antara siswa yang telah mendapatkan pendidikan wirausaha ataupun siswa yang belum mendapatkan pendidikan kewirausahaan.

Aspek keyakinan diri dalam berwirausaha menunjukkan pengaruh yang signifikan dari siswa yang telah mendapatkan pendidikan kewirausahaan dan siswa yang belum mendapatkan pendidikan kewirausahaan. Terjadi peningkatan rasa percaya diri pada siswa yang telah mendapatkan pendidikan kewirausahaan apabila dibandingkan dengan siswa yang belum mendapatkan pendidikan kewirausahaan. Hal tersebut berarti bahwa pendidikan kewirausahaan memberikan pengaruh pada keyakinan diri para siswa. Hasil penelitian yang dilakukan berbeda dengan hasil penelitian Solesvik (2013) yang menyimpulkan terdapat perbedaan antara siswa yang mengikuti pendidikan kewirausahaan dan siswa yang tidak mengikuti pendidikan kewirausahaan pada aspek intensi wirausaha. Perbedaan hasil tersebut dikarenakan oleh aspek kualitas pendidikan kewirausahaan yang dijalankan.

Hasil penelitian yang sama ditunjukkan oleh penelitian yang dilakukan oleh Nabi, et al. (2018) yang menyimpulkan bahwa pendidikan kewirausahaan dari waktu ke waktu memang tidak dapat memberikan peningkatan terhadap aspek intensi wirausaha para siswa. Semakin lama waktu mengikuti pendidikan 
kewirausahaan tidak memberikan jaminan perubahan dan peningkatan minat wirausaha para siswa.

\section{SIMPULAN}

Berdasarkan hasil analisis data penelitian, maka disimpulkan: (1) Nilai ratarata (mean) ESE, EA, dan EI siswa yang telah mendapatkan pendidikan kewirausahaan lebih tinggi apabila dibandingkan dengan nilai rata-rata siswa yang belum mendapatkan pendidikan kewirausahaan; dan (2) EA dan EI tidak terdapat pengaruh yang signifikan antara siswa yang telah mendapatkan pendidikan kewirausahaan dan siswa belum mendapatkan pendidikan kewirausahaan. Sedangkan pada aspek ESE terdapat pengaruh yang signifikan antara siswa yang telah mendapatkan pendidikan kewirausahaan dan siswa yang belum mendapatkan pendidikan kewirausahaan.

\section{DAFTAR PUSTAKA}

Ajzen, I. 2001. Nature and Operation of Attitudes. Annual Review of Psychology, 52(1): 27-58.

Al-Jubari, I., Hassan, A., \& Liñán, F. 2018. Entrepreneurial Intention among University Students in Malaysia: Integrating Self-Determination Theory and the Theory of Planned Behavior. International Entrepreneurship and Management Journal, 15(4): 1323-1342.

Autio, E., Keeley, R., Klofsten, M., Parker, G. G., \& Hay, M. 2001. Entrepreneurial Intent among Students in Scandinavia and in the USA. Enterprise and Innovation Management Studies, 2(2): 145-160.

Badan Pusat Statistik. 2018. Pengangguran Terbuka Menurut Pendidikan Tertinggi yang Ditamatkan 1986-2018 dalam https://www.bps.go.id/ statictable/2009/04/16/972/pengangguran-terbuka-menurut-pendidikantertinggi-yang-ditamatkan-1986---2018.html. Diakses tanggal 20 Desember 2018.

Bae, T. J., Qian, S., Miao, C., \& Fiet, J. O. 2014. The Relationship between Entrepreneurship Education and Entrepreneurial Intentions: A Meta-Analytic Review. Entrepreneurship Theory and Practice, 38(2): 217-254.

Bird, B. 1988. Implementing Entrepreneurial Idea: The Case for Intention. Academy of Management Review, 13(3): 442-453.

Engle, R. L., Dimitriadi, N., Gavidia, J. V., Schlaegel, C., Delanoe, S., Alvarado, I., \& Wolff, B. 2010. Entrepreneurial Intent: A Twelve-Country Evaluation of Ajzen's Model of Planned Behavior. International Journal of Entrepreneurial Behaviour \& Research, 16(1): 35-57. 
Galvão, A., Marques, C. S., \& Marques, C. P. 2018. Antecedents of Entrepreneurial Intentions among Students in Vocational Training Programmes. Education + Training, 60(7): 719-734.

Iakovleva, T., Kolvereid, L., \& Stephan, U. 2011. Entrepreneurial Intentions in Developing and Developed Countries. Education + Training, 53(5): 353370.

Kautonen, T., Van Gelderen, M., \& Fink, M. 2015. Robustness of the theory Of Planned Behavior in Predicting Entrepreneurial Intentions and Actions. Entrepreneurship Theory and Practice, 39(3): 655-674.

Kickul, J., Gundry, L. K., Barbosa, S. D., \& Whitcanack, L. 2009. Intuition Versus Analysis? Testing Differential Models of Cognitive Style on Entrepreneurial Self Efficacy and the New Venture Creation Process. Entrepreneurship Theory and Practice, 33(212): 439-453.

Krueger, N. F., Reilly, M. D., \& Carsrud, A. L. 2000. Competing Models of Entrepreneurial Intentions. Journal of Business Venturing, 15(5): 411-432.

Linan, F. 2008. Skill and Value Perceptions: How Do They Affect Entrepreneurial Intentions? International Entrepreneurship and Management Journal, 4(3): 257-272.

Linan, F., \& Chen, Y. 2009. Development and Cross-Cultural Application of A Specific Instrument to Measure Entrepreneurial Intentions. Entrepreneurship Theory and Practice, 33(3): 593-618.

Mahendra, A. M., Djatmika, E. T., \& Hermawan, A. 2017. The Effect of Entrepreneurship Education on Entrepreneurial Intention Mediated by Motivation and Attitude among Management Students, State University of Malang, Indonesia. International Education Studies, 10(9): 61-69.

Marques, C. S., Ferreira, J. J., Gomes, D. N., \& Rodrigues, R. G. 2012. Entrepreneurship Education: How Psychological, Demographic and Behavioural Factors Predict the Entrepreneurial Intention. Education + Training, 54(8): 657-672.

McGee, J. E., Peterson, M., Mueller, S. L., \& Sequeira, J. M. 2009. Entrepreneurial Self-Efficacy: Refining the Measure. Entrepreneurship Theory and Practice, 33(4): 965-988.

Nabi, G., Walmsley, A., Liñán, F., \& Akhtar, I. 2018. Does Entrepreneurship Education in the First Year of Higher Education Develop Entrepreneurial Intentions? The Role of Learning and Inspiration. Studies in Higher Education, 43(3): 452-467.

Newman, A., Obschonka, M., Schwarz, S., Cohen, M., \& Nielsen, I. 2018. Entrepreneurial Self-Efficacy: A Systematic Review of the Literature on Its Antecedents and Outcomes, and an Agenda for Future Research. Journal of Vocational Behavior, 110(B): 403-419.

Nowiński, W., Haddoud, M. Y., Lančarič, D., Egerová, D., \& Czeglédi, C. 2017. The Impact of Entrepreneurship Education, Entrepreneurial Self-Efficacy and Gender on Entrepreneurial Intentions of University Students in the Visegrad Countries. Studies in Higher Education, 44(2): 361-379.

Nurmaliza, Caska, \& Indrawati, H. 2018. Analysis of Factors Affecting Entrepreneurial Interest of Vocational High School Students in Pekanbaru. 
Journal of Educational Sciences, 2(2): 42-51.

Rauch, A. \& Hulsink, W. 2015. Putting Entrepreneurship Education Where the Intention to Act Lies : An Investigation Into the Impact of Entrepreneurship Education on Entrepreneurial Behavior. Academy of Management Learning \& Education, 14(2): 187-204.

Solesvik, M., Westhead, P., \& Matlay, H. 2014. Cultural factors and entrepreneurial intention. Education + Training, 56(8): 680-696.

Solesvik, M. Z. 2013. Entrepreneurial Motivations and Intentions: Investigating the Role of Education Major. Education + Training, 55(3): 253-271.

Sun, H., Lo, C. T., Liang, B., \& Wong, Y. L. B. 2016. The Impact of Entrepreneurial Education on Entrepreneurial Intention of Engineering Students in Hong Kong. Management Decision, 55(7): 1371-1393.

Sunyoto, Widodo, J., \& Samsudi. 2018. Development of Apprenticeship Model for Vocational School Based on Entrepreneurship. AIP Conference Proceedings, 1941(1): 020039-1 - 020039-8.

Thompson, E. R. 2009. Individual Entrepreneurial Intent: Construct Clarification and Development of an Internationally Reliable Metric. Entrepreneurship Theory and Practice, 33(3): 669-695.

Westhead, P. \& Solesvik, M. Z. 2015. Entrepreneurship Education and Entrepreneurial Intention: Do Female Students Benefit? International Small Business Journal, 34(8): 979-1033. 